\title{
Profil zat besi (Fe) pada ibu hamil dengan anemia di Puskesmas Bahu Manado
}

\author{
${ }^{1}$ Florencia T. Paendong \\ ${ }^{2}$ Eddy Suparman \\ ${ }^{2}$ Hermie M. M. Tendean
}

\author{
${ }^{1}$ Kandidat Skripsi Fakultas Kedokteran Universitas Sam Ratulangi Manado \\ ${ }^{2}$ Bagian Obstetri dan Ginekologi Fakultas Kedokteran Universitas Sam Ratulangi \\ RSUP Prof.dr.R.D. Kandou Manado \\ Email: florenciatiffani7@gmail.com
}

\begin{abstract}
Anemia due to iron deficiency is one of the major causes of anemia among Indonesian pregnant women. In developed country, the deaths of mothers and infants are relate to anemia caused by iron deficiency. This study aimed to obtain the profile of maternal anemia at the primary health care Bahu Manado. This was a descriptive prospective study with a cross sectional design. Samples were sobtained by using total sampling method consisted of 40 pregnant women. Serum iron (SI) was examined among anemic pregnant women. The results showed that of the 40 pregnant women, 13 (32.5\%) had anemia. Of the 13 anemic pregnant women, $8(61.5 \%)$ had decreased SI. The analysis found that there was a relation between age, age of pregnancy, parity, education, and job with anemia and decreased SI. It is recommended to consume enough iron during pregnancy and have a regular check up, and treatment in case that the iron level is not optimal.
\end{abstract}

Keywords: anemia, pregnant woman, iron deficiency

\begin{abstract}
Abstrak: Anemia defisiensi besi merupakan penyebab utama terjadinya anemia pada ibu hamil di Indonesia dengan prevalensi yang cukup tinggi sehingga masih menjadi masalah kesehatan masyarakat. Di negara berkembang kematian ibu dan janin berkaitan dengan anemia pada kehamilan dan kebanyakan anemia pada kehamilan disebabkan oleh defisiensi besi. Penelitian ini bertujuan untuk mengetahui profil zat besi $(\mathrm{Fe})$ pada ibu hamil dengan anemia di Puskesmas Bahu Manado. Jenis penelitian deskriptif prospektif dengan desain potong lintang. Pemilihan sampel menggunakan metode total sampling yaitu dengan menggunakan seluruh populasi berjumlah 40 orang. Serum iron (SI) diperiksa pada ibu hamil dengan anemia. Hasil penelitian menunjukkan dari 40 ibu hamil yang berkunjung ke Puskesmas Bahu Manado, didapatkan 13 (32,5\%) ibu hamil mengalami anemia. Dari 13 ibu hamil yang anemia, didapatkan 8 (61,5\%) ibu hamil mengalami penurunan kadar SI . Hasil analisis mendapatkan hubungan antara usia, usia kehamilan, paritas, pendidikan dan pekerjaan dengan anemia dan penurunan kadar SI pada ibu hamil. Disarankan kepada ibu hamil untuk memenuhi asupan zat besi saat hamil dan melakukan kontrol pemeriksaan serta mendapatkan pengobatan bila kadar zat besi (Fe) tidak berada pada nilai optimal.
\end{abstract}

Kata kunci: anemia, ibu hamil, defisiensi besi

Anemia adalah suatu keadaan dimana kadar hemoglobin $(\mathrm{Hb})$ dalam darah kurang dari normal. Menurut World Health Organization (WHO) dikatakan anemia jika kadar hemoglobin $<11 \mathrm{gr} / \mathrm{dl}$ pada ibu hamil. ${ }^{1}$ Berbagai penyebab anemia antara lain karena defisiensi zat besi yang merupakan penyebab utama anemia pada ibu hamil jika dibandingkan dengan defisiensi zat gizi lain. Ibu hamil cenderung 
kekurangan gizi karena pada masa kehamilan terjadi peningkatan kebutuhan gizi untuk memenuhi kebutuhan ibu dan janin yang di kandung. Pola makan yang salah pada ibu hamil berpengaruh terhadap terjadinya gangguan gizi seperti anemia. ${ }^{2}$

Badan kesehatan dunia WHO (World Health Organization) melaporkan prevalensi ibu hamil yang mengalami defisiensi besi sekitar 35-75\% semakin meningkat seiring dengan pertambahan usia kehamilan dan diperkirakan 30-40\% penyebab anemia karena kekurangan zat besi. $^{3,4}$ Kelainan ini ditandai oleh serum iron (SI) menurun, total iron binding capacity (TIBC) meningkat, saturasi transferin menurun, feritin serum menurun, pengecatan besi sumsum tulang negatif dan adanya respon terhadap pengobatan dengan preparat besi. ${ }^{5}$ Berdasarkan hasil Survei Kesehatan Rumah Tangga (SKRT), prevalensi anemia pada ibu hamil di Indonesia 40,1\% dan pada tahun 2007 turun menjadi $24,5 \%{ }^{6}$ Berdasarkan hasil Riset Kesehatan Dasar (Riskesdas) tahun 2013, prevalensi anemia pada ibu hamil di Indonesia naik menjadi $37,1 \%{ }^{7}$ Dengan demikian keadaan ini mengindikasi bahwa anemia gizi besi masih menjadi masalah kesehatan masyarakat. Menurut WHO 40\% kematian ibu dinegara berkembang berkaitan dengan anemia pada kehamilan dan kebanyakan anemia pada kehamilan disebabkan oleh defisiensi besi. Dari hasil penelitian sebelumnya, persalinan pada wanita hamil yang menderita anemia defisiensi besi didapatkan 12-28\% kematian janin, 30\% kematian perinatal dan 7-10\% angka kematian neonatal. ${ }^{8}$

Mengingat besarnya dampak buruk anemia defisiensi zat besi pada wanita hamil dan janin, maka diperlukan perhatian cukup terhadap masalah ini. Dengan diagnosis yang cepat serta penatalaksanaan yang tepat komplikasi dapat diatasi serta akan mendapatkan prognosis yang lebih baik.

Puskesmas Bahu Manado merupakan pusat layanan kesehatan yang banyak diminati oleh penduduk dikarenakan
Puskesmas Bahu Manado memiliki wilayah kerja yang terdiri dari lima kelurahan, yaitu kelurahan Bahu, Batu Kota, Kleak, Winangun 1 dan Winangun 2. Dari segi geografis Puskesmas Bahu Manado hampir mencakup keseluruhan wilayah dengan batas sebelah utara yaitu kecamatan Sario dan Laut Manado, sebelah timur yaitu kecamatan Sario dan Pineleng, sebelah selatan yaitu kecamatan Pineleng dan sebelah barat yaitu kelurahan Malalayang 1 Timur. Puskesmas Bahu Manado juga merupakan lokasi yang strategis karena jaraknya dekat dengan RSUP Prof. DR. R. D. Kandou dan Laboratorium Klinik Prodia.

Penelitian ini bertujuan untuk mendapatkan profil zat besi $(\mathrm{Fe})$ pada ibu hamil dengan anemia di Puskesmas Bahu Manado.

\section{METODE PENELITIAN}

Jenis penelitian ini ialah deskriptif prospektif dengan desain potong lintang. Penelitian ini dilakukan di Puskesmas Bahu Manado pada bulan November-Desember 2015. Pemilihan sampel menggunakan metode total sampling yaitu semua ibu hamil yang berkunjung di Puskesmas Bahu Manado pada periode penelitian dengan menggunakan seluruh populasi yang ada berjumlah 40 orang. Pemeriksaan darah dilakukan untuk pemeriksaan hemoglobin dan pengukuran profil zat besi (Fe) yang dilakukan di Laboratorium Klinik Prodia, jalan Sam Ratulangi nomor 72, Manado. Data yang terkumpul diolah dengan menggunakan aplikasi Statistical Package For Social Sciense (SPSS).

\section{HASIL PENELITIAN DAN BAHASAN}

Selama penelitian, dari 40 ibu hamil yang berkunjung di Puskesmas Bahu Manado dan bersedia dilakukan pengambilan darah untuk pemeriksaan hemoglobin, didapatkan 13 ibu hamil yang mengalami anemia. Pada ke 13 ibu hamil dengan anemia tersebut dilanjutkan dengan pemeriksaan SI. Pada penelitian ini dilakukan analisis yang mencakup kadar 
hemoglobin dan kadar SI. Karakteristik ibu hamil dengan anemia (usia, usia kehamilan, paritas, pendidikan dan pekerjaan) dan kadar SI berdasarkan karakteristik ibu hamil dengan anemia. Data tersebut disajikan dalam bentuk narasi dan tabel.

Tabel 1. Distribusi kadar hemoglobin ibu hamil

\begin{tabular}{ccc}
\hline $\begin{array}{c}\text { Kadar } \\
\text { hemoglobin }\end{array}$ & $\mathbf{n}$ & $\mathbf{\%}$ \\
\hline Rendah & 13 & 32.5 \\
Normal & 27 & 67.5 \\
Total & 13 & 100 \\
\hline
\end{tabular}

Tabel 1 menunjukkan distribusi kadar hemoglobin ibu hamil. Dari 40 ibu hamil, didapatkan ibu hamil dengan kadar hemoglobin rendah berjumlah 13 orang (32,5\%) dan ibu hamil dengan kadar hemoglobin normal berjumlah 27 orang (67,5\%). WHO melaporkan bahwa terdapat $42 \%$ ibu hamil mengalami anemia di negara berkembang. ${ }^{2}$ Berdasarkan hasil Survei Kesehatan Rumah Tangga (SKRT), prevalensi anemia pada ibu hamil di Indonesia 40,1\% dan pada tahun 2007 turun menjadi 24.5\%. ${ }^{6}$ Berdasarkan hasil Riset Kesehatan Dasar (Riskesdas) tahun 2013, prevalensi anemia pada ibu hamil di Indonesia naik menjadi $37,1 \%{ }^{7}$ Dengan demikian, anemia pada ibu hamil masih menjadi masalah kesehatan masyarakat.

Tabel 2 menunjukkan karakteristik ibu hamil dengan anemia. Berdasarkan usia, sampel terbanyak berada pada usia 21-34 tahun dengan jumlah 10 orang (76.9\%). Berdasarkan usia kehamilan, terbanyak pada trimester II dengan jumlah 7 orang (53.8\%).

Berdasarkan paritas, terbanyak pada multigravida dengan jumlah 7 orang (53,8\%). Berdasarkan pendidikan, terbanyak pada tingkat SMA dengan jumlah 7 orang (53,8\%). Berdasarkan pekerjaan terbanyak pada ibu hamil dengan anemia yang bekerja yaitu, 8 orang (61,5\%)

Penelitian ini sesuai dengan penelitian yang dilakukan oleh Pipit pada tahun 2013 di Propinsi Jawa Tengah bahwa usia reproduksi yang baik ialah pada kelompok usia 21-34 tahun. Usia tersebut merupakan usia reproduksi yang baik bagi ibu hamil, akan tetapi walaupun merupakan kelompok usia reproduksi yang baik bagi ibu hamil, pada kelompok usia inilah tingkat kejadian anemia pada ibu hamil sering terjadi. ${ }^{9}$ Selanjutnya, penelitian yang dilakukan oleh Madhavi et al. ${ }^{10}$ melaporkan $79,48 \%$ ibu hamil dengan anemia terbanyak terjadi pada multigravida.

Tabel 2. Karakteristik ibu hamil dengan anemia

\begin{tabular}{lcc}
\hline Karakteristik & $\mathbf{n}$ & $\mathbf{\%}$ \\
\hline Usia & 2 & 15.4 \\
$\leq 20$ & 10 & 76.9 \\
$21-34$ & 1 & 7.7 \\
$\geq 35$ & 13 & 100 \\
$\quad$ Total & 2 & 15.4 \\
\hline Usia kehamilan & & \\
Trimester I & 7 & 53.8 \\
Trimester II & 4 & 30.8 \\
Trimester III & 13 & 100 \\
$\quad$ Total & & \\
Paritas & 6 & 46.2 \\
Primigravida & 7 & 53.8 \\
Multigravida & 13 & 100 \\
Total & & \\
Pendidikan & 7 & 53.8 \\
SMA & 6 & 46.2 \\
Perguruan Tinggi & 13 & 100 \\
$\quad$ Total & & \\
Pekerjaan & 8 & 61.5 \\
Bekerja & 5 & 38.5 \\
Tidak bekerja & 13 & 100 \\
Total & &
\end{tabular}

Menurut United Nation Development Programme (UNDP) tahun 2011, tingkat pendidikan masyarakat Indonesia di tahun 2011 menurun dibanding tahun 2010. Rendahnya pendidikan ibu akan berdampak pada rendahnya pengetahuan ibu yang berpengaruh pada kesadaran ibu untuk mendapatkan pelayanan kesehatan untuk mencegah terjadinya anemia. ${ }^{11}$ Penelitian yang dilakukan oleh Ahmad et al. ${ }^{12}$ menunjukkan ibu hamil yang memiliki pendidikan terakhir SMA lebih sering mengalami anemia dibandingkan dengan 
ibu hamil yang memiliki tingkat pendidikan di Perguruan Tinggi. Tingkat pendidikan ibu hamil yang rendah memengaruhi penerimaan informasi sehingga pengetahuan tentang anemia dan faktorfaktor yang berhubungan dengannya menjadi terbatas.

Tabel 3. Distribusi kadar SI pada ibu hamil dengan anemia

\begin{tabular}{ccc}
\hline $\begin{array}{c}\text { Kadar SI } \\
\text { (serum iron) }\end{array}$ & $\mathbf{n}$ & $\mathbf{\%}$ \\
\hline Rendah & 8 & 61.5 \\
Normal & 5 & 38.5 \\
Total & 13 & 100 \\
\hline
\end{tabular}

Tabel 3 menunjukkan distribusi kadar SI pada ibu hamil dengan anemia. Dari 13 ibu hamil dengan anemia, mayoritas memiliki kadar SI rendah dengan jumlah 8 orang (61,5\%); hanya 5 orang $(38,5 \%)$ memiliki kadar SI normal. Hal ini sejalan dengan penelitian yang dilakukan oleh Sukrat B et al. ${ }^{13}$ bahwa penyebab utama anemia pada ibu hamil karena defisiensi zat besi (43,1\%). Penelitian yang serupa dilakukan di Tanzania pada 150 ibu hamil mendapatkan 32\% mengalami defisiensi zat besi. ${ }^{14}$ Pada ibu hamil terjadi peningkatan kebutuhan zat besi dua kali lipat akibat peningkatan volume darah tanpa ekspansi volume plasma untuk memenuhi kebutuhan ibu dan janin yang dikandung. ${ }^{2,6}$ Peningkatan volume plasma menyebabkan terjadinya hidremia kehamilan atau hemodilusi yang berakibat terjadinya penurunan hematokrit dengan hemoglobin dan hematokrit lebih rendah, TIBC meningkat 15\% sedangkan SI menurun. ${ }^{15}$

WHO sebelumnya melaporkan prevalensi ibu hamil yang mengalami defisiensi besi sekitar 35-75\% dan semakin meningkat seiring dengan pertambahan usia kehamilan dan diperkirakan 30-40\% penyebab anemia karena kekurangan zat besi. $^{3,4}$ Anemia defisiensi besi juga diakibatkan karena intake makanan kaya zat besi tidak mencukupi. Faktor nutrisi tersebut diakibatkan karena kurangnya asupan atau kualitas zat besi yang kurang baik. Karena jumlah asupan saja ternyata belum cukup untuk mencegah anemia, tetapi kualitas zat besi juga harus dipertimbangkan dalam pemilihan makanan yang akan dikonsumsi untuk memenuhi kebutuhan tubuh terhadap zat besi. ${ }^{10}$

Tabel 4. Karakteristik ibu hamil dengan anemia dan kadar SI

\begin{tabular}{|c|c|c|c|c|}
\hline \multirow[t]{2}{*}{ Karakteristik } & \multicolumn{2}{|c|}{ Normal } & \multicolumn{2}{|c|}{ Rendah } \\
\hline & $\mathbf{n}$ & $\%$ & $\mathbf{n}$ & $\%$ \\
\hline \multicolumn{5}{|l|}{ Usia } \\
\hline$\leq 20$ & - & - & 3 & 23.1 \\
\hline $21-34$ & 5 & 38.5 & 5 & 38.5 \\
\hline$\geq 35$ & - & - & - & - \\
\hline \multicolumn{5}{|l|}{ Usia } \\
\hline \multicolumn{5}{|l|}{ Kehamilan } \\
\hline Trimester I & 1 & 7.7 & 1 & 7.7 \\
\hline Trimester II & 2 & 15.4 & 5 & 38.5 \\
\hline Trimester III & 1 & 7.7 & 3 & 23.1 \\
\hline \multicolumn{5}{|l|}{ Paritas } \\
\hline Primigravida & 2 & 15.4 & 4 & 30.8 \\
\hline Multigravida & 3 & 23.1 & 4 & 30.8 \\
\hline \multicolumn{5}{|l|}{ Pendidikan } \\
\hline SMA & 2 & 15.4 & 5 & 38.5 \\
\hline $\begin{array}{l}\text { Perguruan } \\
\text { tinggi }\end{array}$ & 3 & 23.1 & 3 & 23.1 \\
\hline \multicolumn{5}{|l|}{ Pekerjaan } \\
\hline Bekerja & 3 & 23.1 & 5 & 38.5 \\
\hline $\begin{array}{l}\text { Tidak } \\
\text { bekerja }\end{array}$ & 1 & 7.7 & 4 & 30.8 \\
\hline
\end{tabular}

Tabel 4 menunjukkan karakteristik ibu hamil anemia dengan kadar SI. Berdasarkan umur, ibu hamil dengan anemia yang mengalami penurunan kadar SI terbanyak pada usia 21-34 tahun dengan jumlah 5 orang $(38,5 \%)$. Berdasarkan usia kehamilan, terbanyak pada trimester II dengan jumlah 5 orang (38,5\%). Berdasarkan paritas, primigravida dan multigravida sama banyak dengan jumlah 4 orang (30,8\%). Berdasarkan pendidikan, terbanyak pada tingkat SMA dengan jumlah 5 orang (38,5\%). Berdasarkan pekerjaan, terbanyak pada ibu hamil anemia yang bekerja dengan jumlah 5 orang (38,5\%). Hal ini sejalan dengan penelitian yang dilakukan oleh Taseer et al. ${ }^{16}$ bahwa usia, usia kehamilan, paritas, 
pendidikan dan pekerjaan merupakan faktor resiko terjadinya anemia dalam kehamilan terutama anemia defisiensi zat besi. Disamping itu penelitian yang sama juga dilakukan oleh Siti et al. ${ }^{17}$ yang menunjukkan bahwa anemia defisiensi zat besi dipengaruhi oleh beberapa faktor, antara lain sosial ekonomi, pengetahuan, pendidikan, budaya yang merupakan faktor dasar dan faktor langsung yaitu kurangnya zat besi yang dikonsumsi saat hamil.

\section{SIMPULAN}

Dari hasil penelitian terhadap zat besi (Fe) menggunakan pemeriksaan SI (Serum Iron) yang dilakukan di Laboratorium Klinik Prodia terhadap 13 orang ibu hamil dengan anemia didapatkan jumlah terbanyak ibu hamil dengan anemia memiliki kadar SI rendah sebanyak 61,5\%.

Karakteristik ibu hamil yang anemia dengan kadar SI rendah $(<50$ g/dL $)$ menunjukkan mayoritas pada usia 21-34 tahun, pada trimester II, primigravida dan multigravida sama banyak, pendidikan tingkat SMA, dan ibu hamil yang bekerja.

\section{SARAN}

1. Memenuhi asupan zat besi saat hamil dan melakukan kontrol pemeriksaan zat besi (Fe) untuk memantau kesehatan kehamilan.

2. Mendapatkan pengobatan apabila kadar zat besi (Fe) tidak berada pada nilai optimal (nilai sesuai rujukan).

\section{DAFTAR PUSTAKA}

1. WHO. The prevalence of anaemia in 2011. WHO global database on anaemia geneva. World health organization. 2015. [cited 2015 Nov 25]. Available from:

http://www.unscn.org/layout/modules /news/documents/GlobalPrevalenceA naemia2011_eng.pdf

2. Ojofeitimi EO, Ogunjuyigbe PO, Sanusi, et al. Poor dietary intake of energy and retinol among pregnant women. Pak J Nutr. 2008;7:480-84.

3. Bakta IM. Pendekatan terhadap pasien anemia. In: Sudoyo AW, Setiyohadi B, Alwi I, Simadibrata M, Setiati S, penyunting. Buku Ajar Ilmu Penyakit Dalam (5th ed). Jakarta Pusat: Interna Publishing, 2011; p.109-15.

4. Mirzaie F, Eftekhari N, Goldozeian S, Mahdavinia J. Prevalence of anemia risk factors in pregnant women in Kerman, Iran. Iran J Reprod Med. 2010;8:66-9.

5. Bakta IM, editor. Hematologi Klinik. Jakarta: EGC, 2007; p. 26-39.

6. Elsy N. Faktor-faktor yang berhubungan dengan kejadian anemia pada ibu hamil trimester III di wilayah kerja puskesmas air dingin kota Padang tahun 2012 [Skripsi]. Padang: Fakultas Kedokteran Universitas Andalas; 2012.

7. Pradana RA. Analisis kecacingan ibu hamil dengan anemia di wilayah kerja puskesmas Gatak [Skripsi]. Surakarta: Fakultas Ilmu Kesehatan Universitas Muhammadiyah; 2014.

8. Sudha R, Suryaprabha ML. Prevalence of anaemia and factors influencing anaemia in adolscent girls in urban and rural area of a South Indian city. Int J Pharm Bio Sci. 2013;4:1352-58.

9. Pipit S. Gambaran sikap ibu hamil tentang perawatan payudara selama hamil di pos kesehatan desa Pundungrejo Tawangsari Sukoharjo tahun 2013. Jurnal Kebidanan Indonesia. 2014;5:91-102.

10. Madhavi LH, Singh HKG. Nutritional status of rural pregnant woman. People’s J Sci Res. 2011;4:20-23.

11. Alleyne M, Horne MK, Miller JL. Individual pengobatan untuk anemia defisiensi zat besi pada orang dewasa. Am J Med. 2008;121:943-48.

12. Ahmad N, Kalakoti P, Bano R, Aarif SM. The prevalence of anaemia and associated factors in pregnant women in rural Indian community. Med J Aust. 2010;3:276-80.

13. Sukrat B, Sirichotiyakul S. The prevalence and causes of anemia during pregnancy in Maharaj Nakorn Chiang Mai Hospital. J. Med. Assoc. Thai 2006;89:142-46.

14. Hinderaker SG, Olsen BE, Lie RT, et al. Anemia in pregnancy in rural Tanzania: associations with micronutrients status and infections. Eur J Clin Nutr. 2002;56:192-99 
Paendong, Suparman, Tendean: Profil zat besi (Fe) pada ibu hamil ...

15. Sukasmiyati. Hubungan antara umur kehamilan dan suplementasi tablet besi dengan status anemia ibu hamil di puskesmas Dlingo II Bantul Yogyakarta Tahun 2012 [Skripsi]. Jakarta: Fakultas Kesehatan Masyarakat Universitas Indonesia; 2012.

16. Taseer I, Safdar S, Mirbahar A, Awan Z.
Anaemia in pregnancy and related risk factors in under developed area. Professional Med J Mar 2011;18:1-4.

17. Siti CQ, Herry SD, Siti N. Hubungan antara paritas dan umur ibu dengan anemia pada ibu hamil trimester III tahun 2012. Jurnal Kebidanan. 2013;2:21-25. 